\title{
An improved suppression subtractive hybridization technique to develop species- specific repetitive sequences from Erianthus arundinaceus (Saccharum complex)
}

\author{
Fan Yu ${ }^{1}$, Yongji Huang ${ }^{1}$, Ling Luo ${ }^{1}$, Xueting $\mathrm{Li}^{1}$, Jiayun $\mathrm{Wu}^{1,2^{*}}$, Rukai Chen ${ }^{1}$, Muqing Zhang ${ }^{3}$ and Zuhu Deng ${ }^{1,3,4^{*}}$
}

\begin{abstract}
Background: Sugarcane has recently attracted increased attention for its potential as a source of bioethanol and methane. However, a narrow genetic base has limited germplasm enhancement of sugarcane. Erianthus arundinaceus is an important wild genetic resource that has many excellent traits for improving cultivated sugarcane via wide hybridization. Species-specific repetitive sequences are useful for identifying genome components and investigating chromosome inheritance in noblization between sugarcane and E. arundinaceus. Here, suppression subtractive hybridization (SSH) targeting E. arundinaceus-specific repetitive sequences was performed. The five critical components of the $\mathrm{SSH}$ reaction system, including enzyme digestion of genomic DNA (gDNA), adapters, digested gDNA concentrations, primer concentrations, and LA Taq polymerase concentrations, were improved using a stepwise optimization method to establish a SSH system suitable for obtaining $E$. arundinaceus-specific gDNA fragments.

Results: Specificity of up to $85.42 \%$ was confirmed for the SSH method as measured by reverse dot blot (RDB) of an E. arundinaceus subtractive library. Furthermore, various repetitive sequences were obtained from the E. arundinaceus subtractive library via fluorescence in situ hybridization (FISH), including subtelomeric and centromeric regions. EaCEN2-166F/R and EaSUB1-127F/R primers were then designed as species-specific markers to accurately validate $E$. arundinaceus authenticity.
\end{abstract}

Conclusions: This is the first report that E. arundinaceus-specific repetitive sequences were obtained via an improved SSH method. These results suggested that this novel SSH system could facilitate screening of species-specific repetitive sequences for species identification and provide a basis for development of similar applications for other plant species.

Keywords: Sugarcane, E. arundinaceus, Suppression subtractive hybridization, Fluorescence in situ hybridization, Species-specific repetitive sequences

\section{Background}

Rising energy demands are placing increasing pressure on finite oil reserves, with largely negative effects such as increased pollution and carbon emissions. Efforts have in expanded to increase the commercial production of ethanol, which is considered to be the most promising biofuel produced from renewable resources. The conver-

\footnotetext{
*Correspondence: dengzuhu@163.com; jiayunng@163.com

${ }^{1}$ National Engineering Research Center for Sugarcane, Fujian Agriculture and Forestry University, Fuzhou 350002, Fujian, China

Full list of author information is available at the end of the article
}

sion of lignocellulosic materials into ethanol fuel is an attractive and promising method that involves renewable raw materials [1-3]. Among various agricultural crop byproducts, sugarcane bagasse is the most abundant lignocellulosic material in tropical countries and has been used for bioethanol and methane production $[4,5]$. Sugarcane (Saccharum spp.) is mainly used for sugar production and as a clean energy substrate [6]. Unfortunately, the narrow genetic base of sugarcane has limited its resistance to face the possible impact of climate change on bioenergy production [7]. Hence, novel

(c) The Author(s). 2018 Open Access This article is distributed under the terms of the Creative Commons Attribution 4.0 International License (http://creativecommons.org/licenses/by/4.0/), which permits unrestricted use, distribution, and 
sugarcane varieties that have high yields and resistance to various stresses, both biotic and abiotic, are needed.

The genus Saccharum is an important member of the Poaceae family. The most widely considered concept by sugarcane breeder is that it consists of six species, including Saccharum officinarum, Saccharum robustum, Saccharum spontaneum, Saccharum sinense, Saccharum barberi, and Saccharum edule [8]. S. spontaneum is widely recognized as the most primitive species within the genus Saccharum, whereas S. robustum has been postulated to be the progenitor of the high sugar content species, S. officinarum [9]. These three species represent the basic species within the genus Saccharum. S. sinense and $S$. barberi are natural hybrids between $S$. officinarum and $S$. spontaneum $[10,11]$. In addition, $S$. edule may be a cross between Saccharum and its closely related genus [12]. The genus Saccharum and its related wild genus, including Miscanthus, Sclerostachya, Erianthus, and Narenga, constitute the Saccharum complex [13], which is an important wild germplasm resource that can be used to broaden the genetic basis of sugarcane [14]. Several reports indicated that Erianthus belongs to Saccharum based on the presence/absence of awn whereas this is not exactly. The criteria to differentiate these two genera vary, but recent studies suggested that Saccharum and Erianthus are distinct genera based on various lines of molecular evidence [15-19]. As such, the Saccharum complex is broadly accepted to indicate the relationship between these species. Erianthus arundinaceus is a related wild species that has desirable agronomic traits for sugarcane improvement, such as high biomass, vigor, ratooning ability, drought tolerance, and water logging, as well as resistance to pests and disease [13, 20-23]. E. arundinaceus is already considered to be one of the most popular germplasm sources for crossing in sugarcane improvement. However, due to genomic divergence between sugarcane and closely related genera, the available molecular markers derived from closely related genera is limited. Therefore, species-specific repetitive sequences would be useful for identifying the genome or chromosome composition of interspecific or intergeneric hybrids and to monitor alien introgression in their progeny [24]. Interestingly, most species-specific markers have been identified as repetitive DNA sequences. Higher plants are known to contain large numbers of repetitive DNA sequences, which may be dispersed throughout the genome or tandemly arrayed at certain chromosome regions [25, 26]. Previously, repetitive DNA sequences were referred to as "junk DNA" because few discernible functions could be assigned to these regions [27]. However, an increasing amount of cytological and genomic sequencing data revealed that repetitive sequences play a significant role in chromosomal rearrangements, genomic differentiation and evolution [26]. Many of these repetitive DNA sequences have been identified as molecular markers in plants [28, 29]. For sugarcane, however, the amount of available sequence information that would allow the identification of molecular markers is limited and thus accurate identification at a species level that is fundamental for research on these plants is difficult.

A variety of approaches for plant species identification have been used, each varying in sensitivity, specificity, cost, and efficacy. Conventional methods of species identification mainly rely on morphology and physiological biochemistry, but the accuracy of these methods for species identification can be compromised by the influence of external environmental conditions. To overcome these challenges, genome-based approaches using polymerase chain reaction (PCR) and sequencing have shown promise as highly sensitive tools for species identification, including amplified fragmented length polymorphism (AFLP), arbitrarily primed PCR (AP-PCR), randomly amplified polymorphic DNA (RAPD), restriction length polymorphism (RFLP), inter simple sequence repeat (ISSR) anchored PCR, simple sequence repeat polymorphism (SSR), and single nucleotide polymorphism (SNP) [30-36]. However, timely and accurate species identification using these methods could not be made due to the long test period or inconsistent results [37]. In addition, genome sequencing can greatly facilitate the identification of species-specific repetitive sequences, although for sugarcane the cost and accuracy of genome sequencing is currently prohibitive due to its genomic complexity and that of related species [38]. Hence, a rapid and reliable identification method that allows both species identification and phenotype determination is needed to discover species-specific repetitive sequences.

Several molecular methods, including $\mathrm{SSH}$, differential display PCR (DD-PCR) and representational difference analysis (RDA) have already been introduced into routine detection approaches or are currently under investigation for their performance in both species identification and phenotype characterization [39-41]. However, many organisms lack well-defined systems for determining lineage, and mapping remains difficult or impossible for genes that lack easily recognizable phenotypes. Among these methods, SSH, invented in 1996 by Diatchenko et al., is an effective method for isolation of specific DNA fragments that can be used to differentiate two closely related species [42-45]. A key feature of this method is simultaneous normalization and subtraction steps that respectively equalize the abundance of DNA fragments within the target population and exclude sequences common to the two populations being compared [43]. Species-unique gDNA fragments could be used as species-specific probes capable of distinguishing 
their 'target' species from all other species [46-50] and enable the profiling of genetic diversity in an environmental metagenome [51]. These advantages make SSH a rapid and accurate detection method that has been widely used for species identification. Li et al. [40] demonstrated that specific DNA fragments produced by SSH could be used as species-specific probes for the identification of five species of the genus Dendrobium. Ge et al. reported that genome-specific molecular markers obtained by SSH were applicable for detection of chromosomes or chromosomal fragments of Lophopyrum elongatum in a wheat background [52]. These studies provided valuable insights into gDNA subtraction between different species for obtaining tester-specific DNA sequences in plants using SSH. Considering the complex genetic background of modern sugarcane, which is both multiploid and aneuploid and has high number of chromosomes $(\sim 120)$, development of a rapid and effective method for species identification is critical.

The aim of this study was to establish a SSH technology optimization system for rapid and systematic screening of species-specific repetitive sequences of the entire genome from $E$. arundinaceus, a polyploid species. Furthermore, E. arundinaceus-specific repetitive sequences were used as a probe for physical mapping of $E$. arundinaceus chromosomes. According to chromosome location, two pairs of primers were designed to accurately identify E. arundinaceus authenticity. This improved $\mathrm{SSH}$ method is executable and efficient. It will be powerful for obtaining species-specific repetitive sequences in other plant for accurate and rapid identification of species. Additionally, these probes could be further used to establish $E$. arundinaceus chromosome karyotypes and investigate chromosome inheritance in the progeny of crosses between sugarcane and E. arundinaceus $[53,54]$.

\section{Results}

The SSH optimization system

Restriction enzyme digestion of $E$. arundinaceus gDNA

To determine whether E. arundinaceus gDNA was completely digested, the digested gDNA was analyzed by agarose gel. Results showed that the size distribution of either HaeIII or AluI-digested gDNA was longer than $2 \mathrm{~kb}$, even though the digestion time was as long as $4 \mathrm{~h}$ (Fig. 1, Lanes 5 and 6). Meanwhile, DNA double digested with both HaeIII and AluI showed a marked decrease in size to 0.1 to $2 \mathrm{~kb}$, and appeared as a smear for all samples after 1 to $4 \mathrm{~h}$ of incubation (Fig. 1, Lanes 1 to 4 ), indicating that the digestion had progressed to completion after $1 \mathrm{~h}$.

\section{Adapter ligation efficiency analysis}

We designed three different adapters (RsaI adapters, HaeIII adapters, and AluI adapters) to screen the

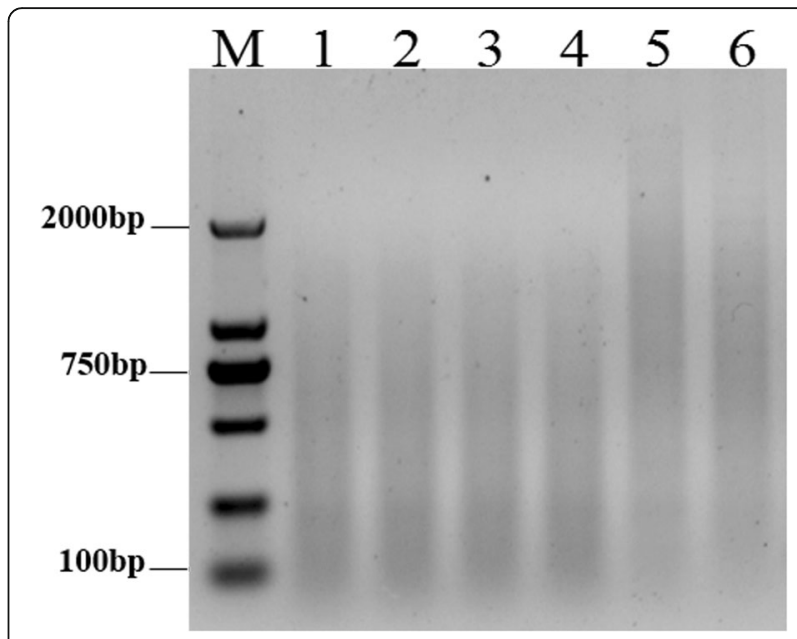

Fig. 1 Enzyme digestion of genomic DNA. M: 2000 bp marker; $E$. arundinaceus gDNA double digested for $1 \mathrm{~h}$ (Lane 1); $2 \mathrm{~h}$ (Lane 2); $3 \mathrm{~h}$ (Lane 3); $4 \mathrm{~h}$ (Lane 4); E. arundinaceus gDNA digested for $4 \mathrm{~h}$ with Haelll (Lane 5) or Alul (Lane 6)

appropriate adapter that could efficiently ligate with the digested gDNA. 28S-204F/R primers were designed to analyze the ligation efficiency of digested DNA. To avoid other factors that could influence ligation efficiency, four different primer combinations were used to the detect ligation efficiency of the different adapters. The AluI adapters had the highest ligation efficiency relative to the HaeIII adapters and RsaI adapters (Fig. 2a). ImageJ analysis showed that the $A l u \mathrm{I}$ adapter bands had the highest average intensity as calculated from the average of signal intensities for three scans. Hence, AluI adapters were used.

To determine the optimal concentration of the digested DNA to use for ligation reaction, four concentrations (50,100, 150, and $200 \mathrm{ng}$ ) were used to ligate with the AluI adapters. Among these different concentrations, the ligation efficiency was highest for $150 \mathrm{ng}$ digested DNA (Additional file 1: Figure S1). Thus, $150 \mathrm{ng}$ digested gDNA was used to ligate to the AluI adapters and the reaction mix was incubated for $2 \mathrm{~min}$ at $72{ }^{\circ} \mathrm{C}$ in a thermal cycler to extend the adaptors. Gel electrophoresis showed that the experimental band that the AluI adapters ligated with $28 \mathrm{~S}$ rDNA fragment was 100 bp larger than the control tester DNA fragments without the AluI adapters (Fig. 3a). ImageJ analysis indicated that the experimental band intensity was $25 \%$ greater than that of the control tester DNA fragments (Fig. 3b), suggesting at least $25 \%$ of the digested DNA fragments had adapters on both ends.

To achieve optimal amplification efficiency, the two-step PCR reaction system was adjusted according to the primers used and LA Taq polymerase as described in the Materials and Methods. Primary PCR and secondary PCR were performed with different temperature 


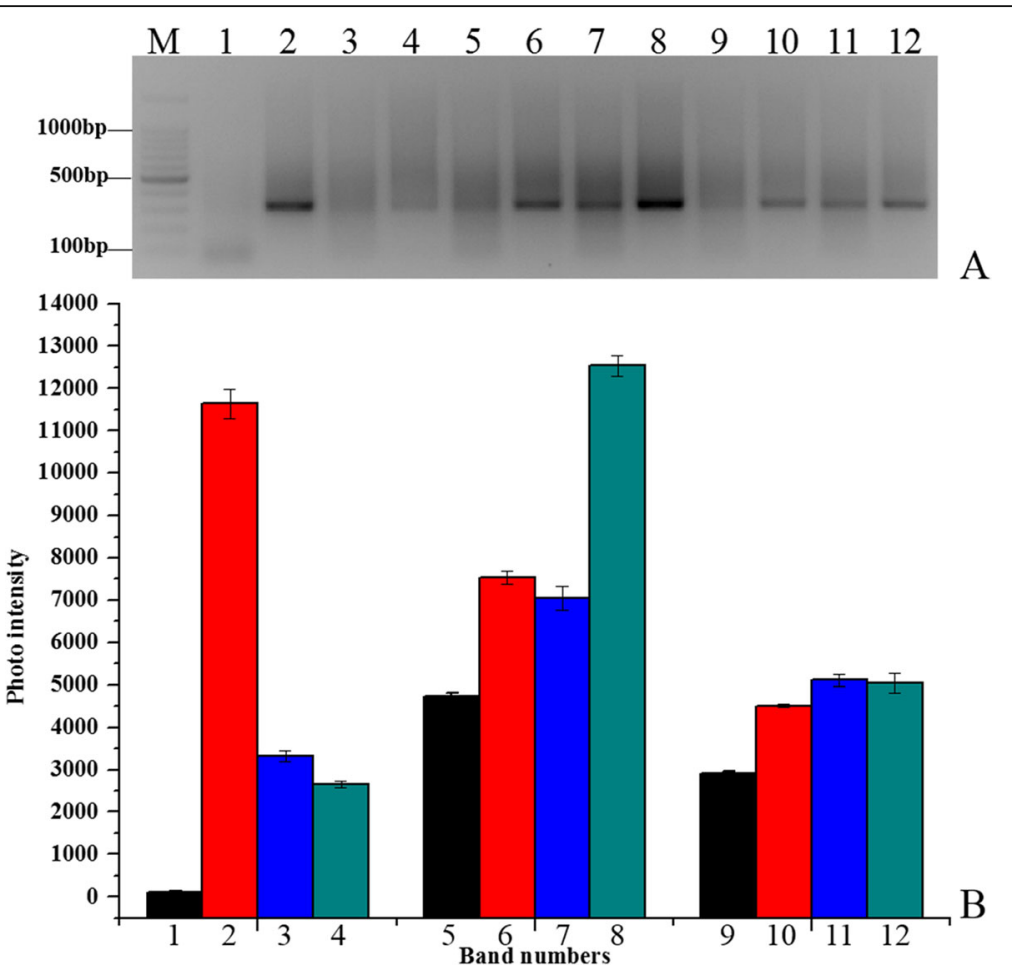

Fig. 2 Adaptor ligation efficiency. Electrophoretic detection (a) and analysis of band intensity (b). M: 100 bp marker Lane 1: Haelll adapter 1 primer 1/ 204F; Lane 2: Haell adapter 1 primer 1/204R; Lane 3: Haell adapter 2R primer 1/204F; Lane 4: Haell adapter 2R primer 1/204R; Lane 5: Alul adapter 1 primer 1/204F; Lane 6: Alul adapter 1 primer 1/204R; Lane 7: Alul adapter 2R primer 1/204F; Lane 8: Alul adapter 2R primer 1/204R; Lane 9: Rsal adapter 1 primer 1/204F; Lane 10: Rsal adapter 1 primer 1/204R; Lane 11: Rsal adapter 2R primer 1/204F; Lane 12: Rsal adapter 2R primer 1/204R

gradients ranging from $62{ }^{\circ} \mathrm{C}$ to $68{ }^{\circ} \mathrm{C}$. In primary PCR, two primer concentrations $(10$ and $20 \mu \mathrm{M})$ and two LA Taq polymerase concentrations ( 0.5 and $1 \mathrm{U}$ ) were used for PCR amplification (Additional file 2: Figure S2a-c and Fig. 4). Among the concentrations tested, $20 \mu \mathrm{M}$ primer with $1 \mathrm{U}$ LA Taq polymerase yielded the best results (Fig. 4). The unsubtracted products appeared as a diffuse band

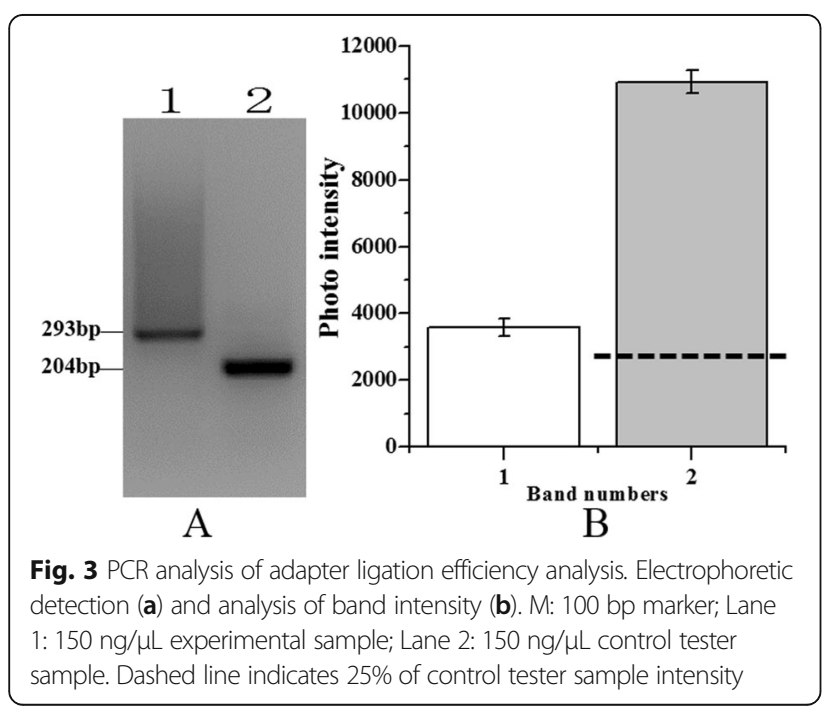

of $0.2-2 \mathrm{~kb}$, whereas the subtracted products appeared as a smear that had weak intensity and a smaller size (Fig. 4). In secondary PCR, two primer concentrations $(20$ and $30 \mu \mathrm{M})$ and two LA Taq polymerase concentrations ( 0.5 and $1 \mathrm{U})$ were used for PCR amplification (Additional file 3: Figure S3a-c and Fig. 4), with $30 \mu \mathrm{M}$ primer and 1 U LA Taq polymerase providing complete amplification (Fig. 4). Both the unsubtractive and subtractive products appeared as a diffuse band, whereas the subtracted products appeared as a number of distinct bands (Fig. 4). This result demonstrated that subtractive products were successfully obtained using the improved amplification system.

\section{The efficiency of SSH PCR products}

Subtractive efficiency performed by PCR detection using $28 \mathrm{~S}-204 \mathrm{~F} / \mathrm{R}$ primers showed that the unsubtracted product appeared as a weak band after 18 cycles, whereas the subtracted product did not produce an obvious band until 24 cycles were reached (Fig. 5). This result showed that $28 \mathrm{~S}$ rRNA gene reduction was successfully achieved in a control sugarcane gDNA sample (Fig. 5).

As the cloning and screening efficiency using this method was unknown, up to 192 (two 96-well plates) white color clones were selected from an E. arundinaceus subtractive library. To eliminate as many false positive 


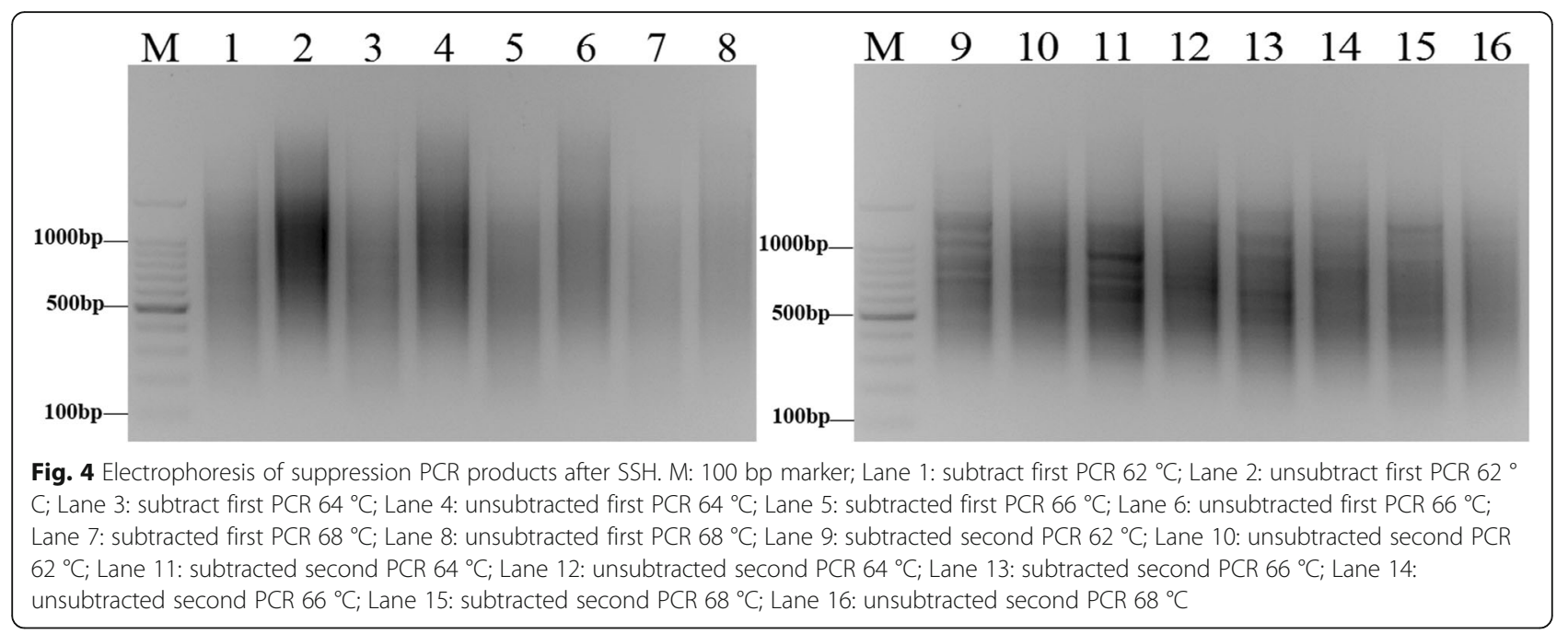

clones as possible, the nest primer set $1 / 2 \mathrm{R}$ rather than the M13F/R primer set was used to amplify the selected clones, so that the recombinant clones were amplified by PCR. A total of 135 positive clones were obtained from a subtractive library of $E$. arundinaceus. The ratio of positive clones was $70.31 \%$, and the clones were $60-1000 \mathrm{bp}$. This result verified that the improved SSH system was suitable for cloning into the pMD19-T vector and that the clones were incorporated with high efficiency.

\section{Screening E. arundinaceus-specific sequences by RDB}

To obtain proof of principle for SSH specificity, RDB was performed by hybridization with $E$. arundinaceus (Fig. 6a) and sugarcane (Fig. 6b) gDNA. As predicted, obvious signals for the 45S rDNA, 5S rDNA and Cassandra positive controls were observed, whereas little or no signal was observed for the negative control using $\mathrm{ddH}_{2} \mathrm{O}$. Thus, the hybridizations were successful. In an $E$. arundinaceus subtractive library, $41 \mathrm{E}$. arundinaceus-specific clones were obtained from 48 clones that represented different sizes among the 135 positive clones, and signals were only observed for E. arundinaceus (Fig. 6a). The RDB results showed that the improved SSH technology yielded an E. arundinaceus-specific rate of up to
$85.42 \%$ in a subtractive library between $E$. arundinaceus and sugarcane.

\section{Localization of E. arundinaceus-specific repetitive sequences in E. arundinaceus chromosomes using FISH}

FISH was performed using chromosome preparations made from Hainan 92-77 root tips and 41 E. arundinaceus-specific DNA sequences as probes. FISH analysis to locate $E$. arundinaceus chromosomes showed two location types, in centromeric regions (Fig. 7a-c, Additional file 4: Table S1) and subtelomeric regions (Fig. 7d, e, Additional file 4: Table S1). Interestingly, EaCEN1 only had six signal sites on the chromosomes (Fig. 7a), whereas EaSUB2 localized to the subtelomeric regions at one or both ends of most chromosomes. Some chromosomes showed no hybridization signal (Fig. 7d). This result indicated that various repetitive sequences could be obtained from the $E$. arundinaceus subtractive library that could be used for karyotype analysis of $E$. arundinaceus.

\section{Species identification with species-specific primers}

Combined with the FISH results, two sequences were selected to design primers to target the subtelomeric and centromeric regions. To confirm the validity of the species-specific primers, species identification

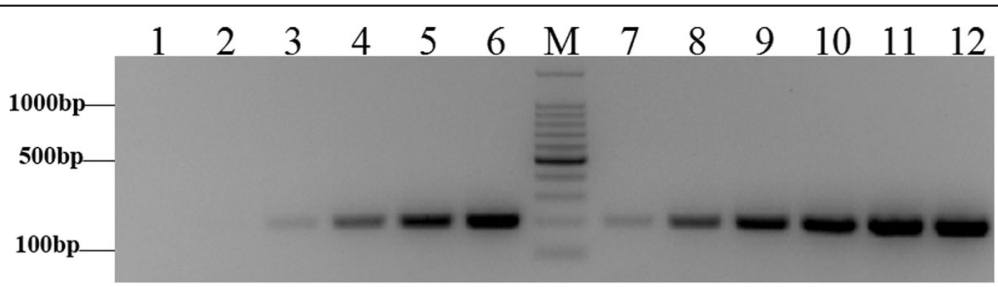

Fig. 5 SSH efficiency. M: 100 bp marker; Lanes 1-6: products of subtracted DNA by 18, 21, 24, 27, 30, and 33 cycles; Lanes 7-12: products of unsubtracted DNA by 18, 21, 24, 27, 30, and 33 cycles 


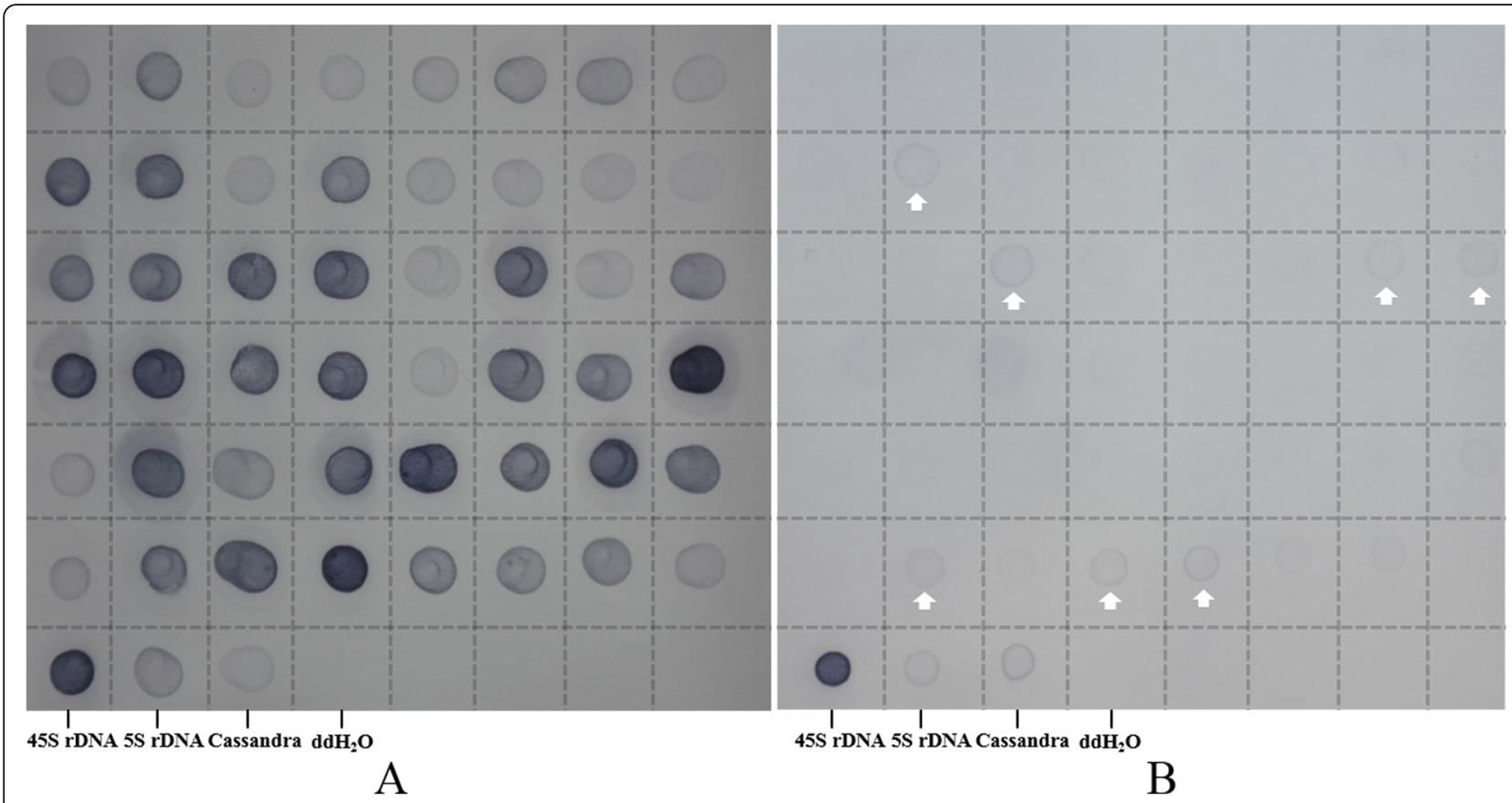

Fig. 6 RDB hybridization of E. arundinaceus-specific sequences. 48 probes were printed in gDNA of E. arundinaceus (a) and sugarcane (b). Arrows indicate non-specific positive

experiments were carried out by PCR using E. arundinaceus-specific primers to amplify $E$. arundinaceus and sugarcane gDNA. Three primer pairs were designed according to EaCEN2 and EaSUB1, and one pair of primers was obtained (Additional file 4: Table S1). PCR amplification with EaCEN2-166F/R showed that the expected bands were only observed in five $E$. arundinaceus samples and six E. arundinaceus-derived $\mathrm{F}_{1}$ hybrids samples (Fig. 8), and a similar result was obtained using EaSUB1-127F/R (Fig. 9). Thus, these primers could be used to identify authentic E. arundinaceus and sugarcane hybrids.

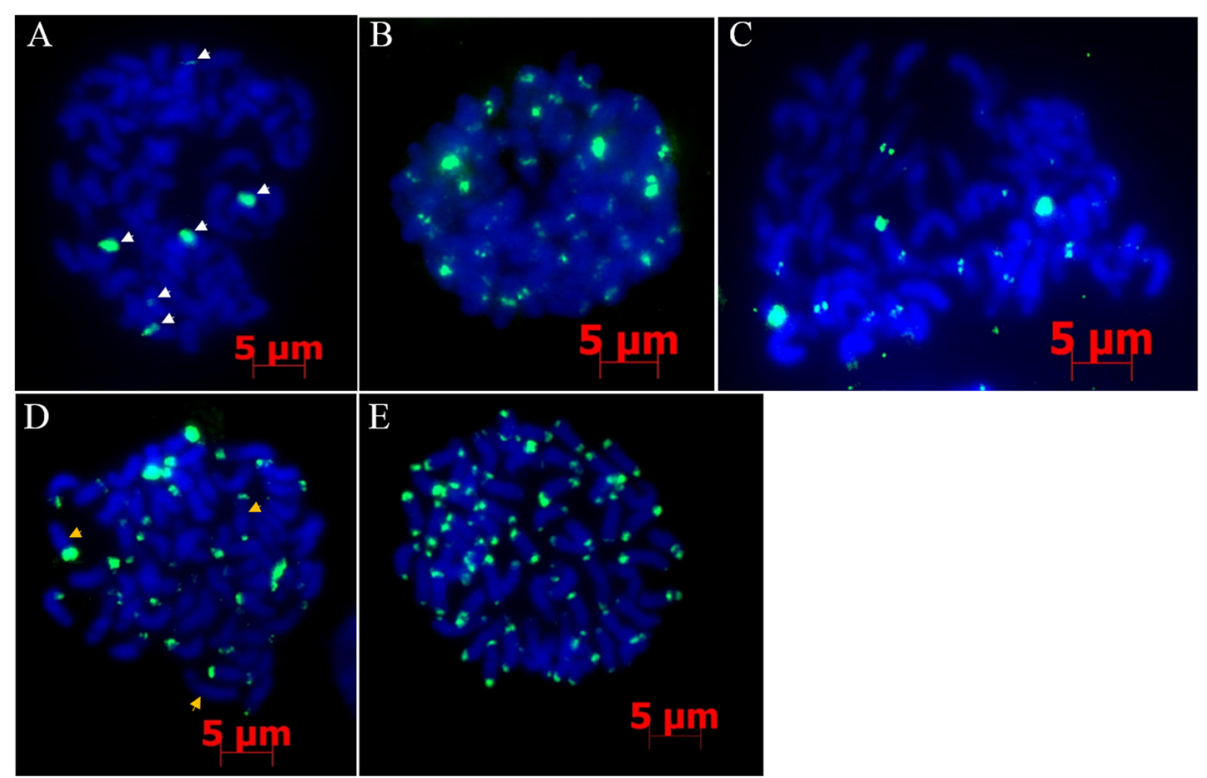

Fig. 7 FISH mapping of E. arundinaceus-specific probes in Hainan 92-77. Five E. arundinaceus-specific probes, EaCEN1 (a), EaCEN2 (b), EaCEN3 (c), EaSUB2 (d), EaSUB1 (e), were mapped to metaphase chromosomes. Specific FISH signals were detected using these five repeat probes. White arrows indicate six signals and three signal types, respectively. Bar $=5 \mu \mathrm{m}$ 


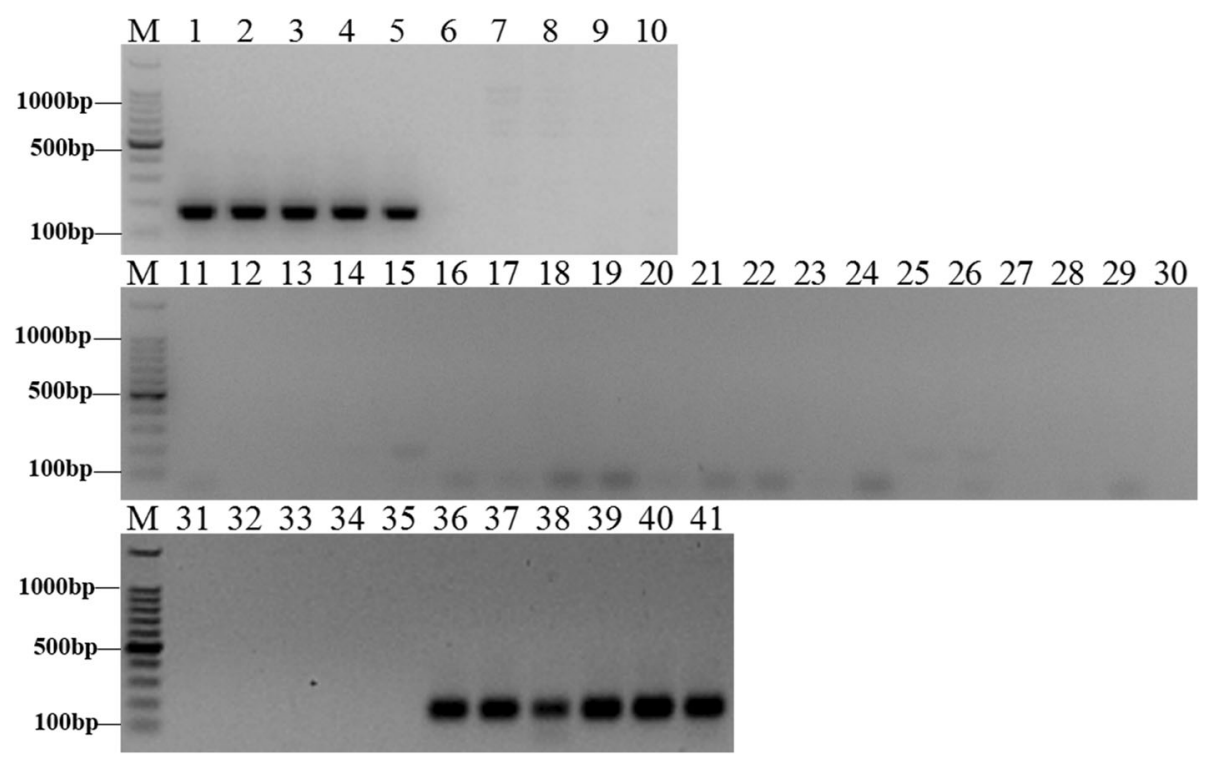

Fig. 8 Amplification profile of the specific primer EaCEN2-166F/R. M: 100 bp marker; Lane 1: Hainan 92-77; Lane 2: Hainan 92-105; Lane 3: Yunnan 83-180; Lane 4: Yunnan 82-30; Lane 5: Yunnan 82-80; Lane 6: Badila; Lane 7: Loethers; Lane 8: Luohan Zhe; Lane 9: Vietnam Niuzhe; Lane 10: Black Cheribon; Lane 11: 51NG3; Lane 12: NG77-004; Lane 13: 51NG63; Lane 14: 57NG208; Lane 15: Daye; Lane 16: Yunnan 75-2-11; Lane 17: Fujian 89-1-19; Lane 18: Fujian 92-1-11; Lane 19: Fujian 89-1-18; Lane 20: Yunnan 82-50; Lane 21: Hetang Zhuzhe; Lane 22: Wenshan Zhuzhe; Lane 23: Uba; Lane 24: Guangdong Zhuzhe; Lane 25: Guangxi Zhuzhe; Lane 26: Nagans; Lane 27: Panshi; Lane 28: Katha; Lane 29: Saretha; Lane 30: Mungo; Lane 31: R570; Lane 32: ROC22; Lane 33: CP84-1198; Lane 34: ROC16; Lane 35: ROC10; Lane 36:Yacheng96-40; Lane 37:Yacheng96-41; Lane 38:Yacheng96-43; Lane 39:Yacheng96-45; Lane 40:Yacheng96-66; Lane 41:Yacheng96-69
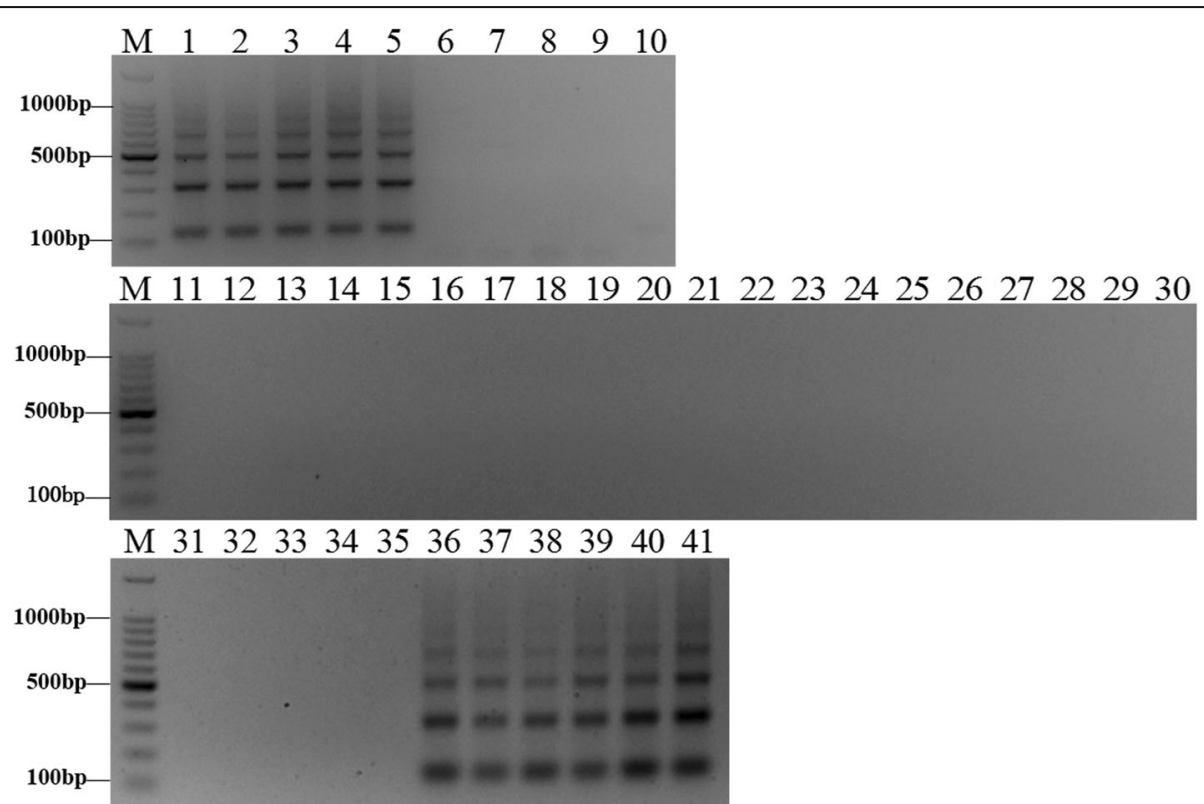

Fig. 9 Amplification profile of the specific primer EaSUB1-127F/R. M: 100 bp marker; Lane 1: Hainan 92-77; Lane 2: Hainan 92-105; Lane 3: Yunnan 83-180; Lane 4: Yunnan 82-30; Lane 5: Yunnan 82-80; Lane 6: Badila; Lane 7: Loethers; Lane 8: Luohan Zhe; Lane 9: Vietnam Niuzhe; Lane 10: Black Cheribon; Lane 11: 51NG3; Lane 12: NG77-004; Lane 13: 51NG63; Lane 14: 57NG208; Lane 15: Daye; Lane 16: Yunnan 75-2-11; Lane 17: Fujian 89-1-19; Lane 18: Fujian 92-1-11; Lane 19: Fujian 89-1-18; Lane 20: Yunnan 82-50; Lane 21: Hetang Zhuzhe; Lane 22: Wenshan Zhuzhe; Lane 23: Uba; Lane 24: Guangdong Zhuzhe; Lane 25: Guangxi Zhuzhe; Lane 26: Nagans; Lane 27: Panshi; Lane 28: Katha; Lane 29: Saretha; Lane 30: Mungo; Lane 31: R570; Lane 32: ROC22; Lane 33: CP84-1198; Lane 34: ROC16; Lane 35: ROC10; Lane 36:Yacheng96-40; Lane 37:Yacheng96-41; Lane 38:Yacheng96-43; Lane 39:Yacheng96-45; Lane 40:Yacheng96-66; Lane 41:Yacheng96-69 


\section{Discussion}

Advantages of SSH technology to screen species-specific DNA fragments and identify species

E. arundinaceus has significant potential as a germplasm source for sugarcane breeding. There are multiple reports of successful cross-hybridization between $E$. arundinaceus and sugarcane $[53,54]$ and the various resulting progeny showed broad chromosome translocations between Saccharum spp. and E. arundinaceus [55]. Thus, a routine and reliable approach to identify $E$. arundinaceus-derived hybrids is needed to improve the efficiency of sugarcane breeding. SSH is a widely used technology to obtain species-specific sequences and this approach forms the foundation for many other methods [56-60]. Furthermore, a significant number of studies and applications have demonstrated the feasibility of SSH in plants $[61,62]$. Currently, $\mathrm{SSH}$ has been used to select species-specific sequences in only a few plants. However, SSH affords many unique advantages, including high sensitivity, high specificity, low false positive rate and abundant differential sequences [40, 52]. In this study, we developed an improved SSH system to produce $E$. arundinaceus-specific repetitive sequences between sugarcane and E. arundinaceus. Findings from this study indicated that this improved SSH method is an inexpensive and efficient tool to capture E. arundinaceus-specific repetitive sequences, and thus this approach could have substantial potential for further identification of species-specific repetitive sequences in other plants. Since higher plants contain many repetitive sequences, during PCR amplification high copy number and short sequences are first amplified, whereas sequences having a low copy number and long sequences have limited amplification. Thus, sequences having a high copy number and shorter lengths are more easily obtained in a SSH library due to this migration enrichment [63]. The phenomenon of high copy number of migration is in accord with the aim of this study, which was to enrich repetitive sequences in E. arundinaceus. Our method not only reduced the frequency of low copy number sequences, but also enriched moderately and highly repetitive sequences. Although the final library contained a few copies of DNA fragments, these can be screened out by RDB. Therefore, many species-specific repetitive sequences could be obtained. We chose two $E$. arundinaceus-specific repetitive sequences located in subtelomeric and centromeric regions to design two primers, EaCEN2-166F/R and EaSUB1-127F/R, respectively. Each primer pair accurately identified the authenticity of $E$. arundinaceus among 41 samples.

Key factors for obtaining specific DNA sequences with SSH Originally, SSH was used to screen differentially expressed genes in cDNA and has since been applied to screen differential DNA fragments in gDNA. Unlike cDNA, gDNA is larger and has a more complex structure [64]. Digestion of complete gDNA with restriction enzymes can be used to reduce this complexity and obtain appropriately sized fragments. At the same copy number, longer DNA fragments have higher $\mathrm{C}_{\mathrm{o}}$ t-values compared to shorter fragments [65]. Hence, longer DNA fragments require an increased renaturation time, and insufficient hybridization could produce false positives. In contrast, shorter DNA fragments can be amplified with preference in PCR. Therefore, we digested gDNA with two restriction enzymes to ensure that the digested fragments were around $2 \mathrm{~kb}$. This approach could also effectively eliminate secondary structures present in long DNA fragments. In this study, the digested fragments ranged between 0.1 and $2.0 \mathrm{~kb}$, which effectively improved the likelihood of differentiating $E$. arundinaceus and sugarcane DNA sequences. Additionally, the connection efficiency of adapters played an important role in obtaining different gDNA fragments. An intensity lower than $25 \%$ of the control connection efficiency could result in loss of gDNA fragments. Therefore, instead of RsaI gDNA digestion, we used both HaeIII and $A l u \mathrm{I}$. The adapter sequences were then modified to ensure ligation efficiency, with $A l u \mathrm{I}$-adapters found to have the highest efficiency.

Thorough hybridization subtraction was also critical for improving the specific positive rate and doubling of the hybridization time produced different outcomes. In earlier studies, the first hybridization time typically ranged from 6 to $12 \mathrm{~h}$, whereas the second was between 12 and $24 \mathrm{~h}[45,63]$. In this study, the two hybridization times were $8 \mathrm{~h}$ and $17 \mathrm{~h}$, respectively, thus almost completely avoiding recombination of single DNA fragments in the first hybridization and ensuring that low amounts of single-stranded DNA were able to form doublestranded DNA in the second hybridization. In addition, the proportion of DNA in the drive group and test group was at least 20:1 to remove homologous DNA sequences in the two distantly related species [63]. Here, we used this ratio for hybridization that allowed the subtraction of homologous DNA sequences between $E$. arundinaceus and sugarcane. If this approach is used to separate closely related species, the ratio of the driver group to the test group should be increased.

\section{Development and utilization of $E$. arundinaceus-specific repetitive sequence probes in FISH}

FISH technology can directly display the position of DNA sequences on chromosomes with high sensitivity and accuracy, which has increased the importance of this technique for studies of molecular and cellular genetics in plants [66]. Repetitive sequence probes can be combined with FISH to track chromosomal inheritance and analyze karyotypes. To date, $\mathrm{C}_{\mathrm{o}} \mathrm{t}-1 \mathrm{DNA}$, Bacterial Artificial Chromosome (BAC) library, Yeast Artificial Chromosome (YAC) library and chromatin 
immunoprecipitation (ChIP) methods have been widely applied in combination with FISH to study plant genomes [67-73]. These methods provide tools to obtain chromosome markers that are directly based on their genomic sequences. However, none have been used as a specific chromosome marker method for species-specific chromosomal tracking, possibly due to the use of non-specific probes. In our study, we obtained several specific repetitive sequences using the SSH method. These sequences could be used to track chromosomes from $E$. arundinaceus-derived hybrids. In particular, six signal sites were detected in Hainan 92-77 using the EaCEN1 probe. D'Hont et al. used pTa71 probes in $E$. arundinaceus with $2 \mathrm{n}=60$ chromosomes to show that the basic chromosome number was $\mathrm{x}=10$ [20]. This finding indicates that these chromosomes were homologous to chromosomes in E. arundinaceus and can be used to analyze specific-chromosome inheritance in offspring resulting from crosses between $E$. arundinaceus and sugarcane. Additionally, repetitive sequences have been used as a probe to identify chromosomes in plants. Indeed, Kato et al. filtered tandem repeat DNA sequences from a random PCR library to generate a distinctive banding pattern for each of the 10 chromosomes in maize [74]. Meanwhile, Zhang et al. also used repetitive sequence probes to enable unequivocal identification of each of the 21 homologous chromosomes in wheat [32]. Here, several $E$. arundinaceus-specific repetitive sequences were obtained from the $E$. arundinaceus subtractive library. These probes were positioned in subtelomeric or centromeric regions, and the signal numbers varied. This outcome could lay the foundation for identifying chromosome karyotypes for $E$. arundinaceus in the future.

\section{Conclusions}

The improved SSH method presented here is shown to be a highly effective and reliable approach for obtaining $E$. arundinaceus-specific repetitive sequences between sugarcane and $E$. arundinaceus that have large and complex genome. Compared with other methods to detect species-specific repetitive sequences that can be used for identifying species lineages, this method has many advantages in that it is simple, rapid, accurate and inexpensive. A key feature of this method is that it can simultaneously capture larger numbers of species-specific sequences from the whole genome. The size and complexity of nucleic acids in genomes of higher eukaryotes produces a reservoir of abundant DNA molecular markers. Our results demonstrated that the ratio of $E$. arundinaceus-specific sequences from screened subtracted clones reached $85.42 \%$, indicating that the improved SSH allows simple screening of larger species-specific probes for definite species authentication. Notably, many tester-specific fragments were $E$. arundinaceus-specific repetitive sequences. Various species-specific repetitive sequences are helpful for exact species identification and karyotype analysis. This method has the potential to improve the efficiency of authentication studies between sugarcane and $E$. arundinaceus. Moreover, the repetitive fragments of $E$. arundinaceus -specific sequences will aid chromosome studies for E. arundinaceus.

\section{Methods}

\section{Plant material and gDNA preparation}

Six different species, sugarcane cultivars and $F_{1}$ hybrids between $E$. arundinaceus and S. officinarum provided by the Research Institute Ruili Station, the Sugarcane Research Institute of Yunnan Agriculture Science Academy, as well as the Hainan Sugarcane Breeding Station, Guangzhou Sugarcane Industry Research Institute were used in this study (Table 1). Leaf tissues from these materials were ground in liquid nitrogen and stored at $80{ }^{\circ} \mathrm{C}$. Total genomic DNA (gDNA) was extracted from young leaves following an improved cetyltrimethyl ammonium bromide (CTAB) methodology [75].

\section{SSH and differential DNA fragment cloning}

SSH was used to isolate DNA fragments present in the target plant materials but absent from the reference clones. The procedure was performed using the PCR-Select Bacterial Genome Subtraction Kit (Clontech), with modifications for $E$. arundinaceus and sugarcane. Three basic species of the genus Saccharum, $S$. officinarum, S. robustum and S. spontaneum (gDNA pooled in 1:1:1 ratio) were assigned as the SSH driver whereas E. arundinaceus was assigned as the $\mathrm{SSH}$ tester. Tester and driver samples were digested with HaeIII, AluI, or both. Adapter ligations were performed using $100 \mathrm{ng}$ digested gDNA that was ligated to $40 \mu \mathrm{M} R s a \mathrm{I}-\mathrm{a}-$ dapter1/2R, HaeIII-adapter1/2R, and Alu-adapter1/2R by $700 \mathrm{U}$ T4 DNA ligation in $10 \mu \mathrm{L}$ reactions. Ligation efficiency was analyzed using $28 \mathrm{~S}-204 \mathrm{~F} / \mathrm{R}$ primers, which were designed according to the conservative $28 \mathrm{~S}$ rDNA sequence of plants. Then, for obtaining the optimal ligation efficiency, four digested gDNA concentrations (50, 100, 150, and $200 \mathrm{ng}$ ) were ligated to $A l u$-adapter1/ 2R. PCR amplification of tester-specific fragments was performed using primers directed to tester ligated adapter sequences. A Veriti 96 -Well Thermal Cycler (ABI, USA) was used for both primary and secondary PCR amplifications. Based on the initial conditions described in the PCR-Select Bacterial Genome Subtraction Kit instruction, primary PCR amplifications were performed using two primer1 (5'-CTAATACGACTCAC TATAGGGC-3') concentrations (10 and $20 \mu \mathrm{M})$ and two LA Taq polymerase concentrations ( 0.5 and $1 \mathrm{U})$ in a $25 \mu \mathrm{L}$ reaction that included $2 \mu \mathrm{L}$ hybridization products, $2.5 \mu \mathrm{L} 10 \times \mathrm{LA}$ buffer, $2 \mu \mathrm{L} 2.5 \mathrm{mM}$ dNTP mixture 
Table 1 Experimental materials

\begin{tabular}{|c|c|c|c|c|c|}
\hline No. & Accession & Species & No. & Accession & Species \\
\hline 1 & Hainan 92-77 & E. arundinaceus & 22 & Wenshan Zhuzhe & S. sinense \\
\hline 2 & Hainan 92-105 & E. arundinaceus & 23 & Uba & S. sinense \\
\hline 3 & Yunnan 82-30 & E. arundinaceus & 24 & Guangdong Zhuzhe & S. sinense \\
\hline 4 & Yunnan 82-80 & E. arundinaceus & 25 & Guangxi Zhuzhe & S. sinense \\
\hline 5 & Yunnan 83-180 & E. arundinaceus & 26 & Nagans & S. barberi \\
\hline 6 & Badila & S. officinarum & 27 & Panshi & S. barberi \\
\hline 7 & Yuenan Niuzhe & S. officinarum & 28 & Katha & S. barberi \\
\hline 8 & Black Cheribon & S. officinarum & 29 & Saretha & S. barberi \\
\hline 9 & Loethers & S. officinarum & 30 & Mungo & S. barberi \\
\hline 10 & Luohan Zhe & S. officinarum & 31 & R570 & S. officinarum, S. spontaneum, S. barberi \\
\hline 11 & $51 N G 3$ & S. robustum & 32 & $\mathrm{ROC} 22$ & S. officinarum, S. spontaneum, S. barberi, S. robustum \\
\hline 12 & NG77-004 & S. robustum & 33 & CP84-1198 & S. officinarum, S. spontaneum, S. barberi \\
\hline 13 & $51 N G 63$ & S. robustum & 34 & $\mathrm{ROC16}$ & S. officinarum, S. spontaneum, S. barberi, S. robustum \\
\hline 14 & $57 N G 208$ & S. robustum & 35 & $\mathrm{ROC} 10$ & S. officinarum, S. spontaneum, S. barberi, S. robustum \\
\hline 15 & Daye & S. robustum & 36 & Yacheng96-40 & S. officinarum, E. arundinaceus \\
\hline 16 & Yunnan 75-2-11 & S. spontaneum & 37 & Yacheng96-41 & S. officinarum, E. arundinaceus \\
\hline 17 & Fujian 89-1-19 & S. spontaneum & 38 & Yacheng96-43 & S. officinarum, E. arundinaceus \\
\hline 18 & Fujian 92-1-11 & S. spontaneum & 39 & Yacheng96-45 & S. officinarum, E. arundinaceus \\
\hline 19 & Fujian 89-1-18 & S. spontaneum & 40 & Yacheng96-66 & S. officinarum, E. arundinaceus \\
\hline 20 & Yunnan 82-50 & S. spontaneum & 41 & Yacheng96-69 & S. officinarum, E. arundinaceus \\
\hline 21 & Hetang Zhuzhe & S. sinense & & & \\
\hline
\end{tabular}

(TaKaRa LA Taq ${ }^{\mathrm{Tm}}$, Takara Biotechnology, Inc.). Secondary PCR amplifications were performed using nest primer 1: 5'-TCGAGCGGCCGCCCGGGCAGAG-3' and nest primer 2R: 5'-AGCGTGGTCGCGGCCGAGAG-3' in a $25 \mu \mathrm{L}$ reaction volume that included $1 \mu \mathrm{L}$ of 10 -fold diluted primary PCR products, $2.5 \mu \mathrm{L} 10 \times \mathrm{LA}$ buffer, $2 \mu \mathrm{L}$ dNTP mixture $(2.5 \mathrm{mM})$, two primer concentrations (20 and $30 \mu \mathrm{M})$, and two LA Taq polymerase concentrations (0.5 and $1 \mathrm{U})$. The primary PCR cycling conditions were: one cycle at $72{ }^{\circ} \mathrm{C}$ for $8 \mathrm{~min}$ to fill in adapters and incubation at $94{ }^{\circ} \mathrm{C}$ for 5 min followed by 30 cycles of $94{ }^{\circ} \mathrm{C}$ for $30 \mathrm{~s}, 66^{\circ} \mathrm{C}$ for $30 \mathrm{~s}$ and $72{ }^{\circ} \mathrm{C}$ for $90 \mathrm{~s}$, and ending with a $5 \mathrm{~min}$ extension and storage at $4{ }^{\circ} \mathrm{C}$. Secondary PCR cycling involved a similar program, but used an annealing temperature of $68{ }^{\circ} \mathrm{C}$. Secondary PCR products were purified using a QIAquick PCR purification kit (Qiagen Inc.) and ligation into the pMD19-T-vector (Qiagen, Inc.). Plasmid DNA was purified using a Plasmid Mini kit I (200) (OMEGA) and then quantified using a NanoVue Plus (GE Healthcare, UK). DNA sequencing was performed by Beijing Genomics Institute (BGI) Co., Ltd. (Shenzhen, China).

\section{Preparation of DIG-labeled probes and RDB}

E. arundinaceus and sugarcane gDNA was labeled by nick translation with digoxigenin (DIG) (Roche, Switzerland).
Reverse dot blots (RDB) were performed to detect $E$. arundinaceus-specific clones. Purified plasmids (50 ng/ $\mu \mathrm{L}$ ) were denatured by heating to $97{ }^{\circ} \mathrm{C}$ for $10 \mathrm{~min}$ and quickly chilled in an ice/water bath for $15 \mathrm{~min}$. The denatured plasmids were transferred onto Amersham Hybond-NC nylon membranes (GE Healthcare, Life Sciences, Indianapolis, IN, United States). Each plasmid $(1 \mu \mathrm{L})$ was spotted onto the membranes, and DNA was fixed to the membrane by UV crosslink using a Stratalin$\operatorname{ker}^{\mathrm{TM}}$ UV Crosslinker (Stratagene, La Jolla, CA, United States). After fixation, the membrane was pre-hybridized for $30 \mathrm{~min}$. RDBs were carried out using a DIG High Prime DNA Labeling and Detection Starter Kit I (Roche, USA) according to the manufacturer's instructions, with slight modifications. High stringency washes were performed following a rinse in wash solution containing $0.2 \times$ saline-sodium citrate (SSC) and $0.1 \%$ sodium dodecyl sulfate before the blots were washed twice at $68{ }^{\circ} \mathrm{C}$ for $15 \mathrm{~min}$ each. Hybridization signals were detected with ChemiDocXRS (Bio-Rad, Hercules, CA, United States).

\section{FISH and primer sequences}

Root tips were obtained from Hainan 92-77. Chromosomal preparations and FISH were performed as described by D'Hont et al. [76]. DIG-labeled differential DNA probes were prepared by PCR reaction with nest 
primer $1 / 2 \mathrm{R}$ in a Veriti 96 -Well Thermal Cycler (ABI, USA). Reactions were performed using a PCR-DIG Probe Synthesis Kit (Roche Diagnostics) according to the manufacturer's instructions, under the following cycling conditions: denaturation for $5 \mathrm{~min}$ at $94{ }^{\circ} \mathrm{C}$; 35 cycles of $30 \mathrm{~s}$ at $94{ }^{\circ} \mathrm{C}, 30 \mathrm{~s}$ at $68{ }^{\circ} \mathrm{C}, 90 \mathrm{~s}$ at $72{ }^{\circ} \mathrm{C}$; and a final extension for $5 \mathrm{~min}$ at $72{ }^{\circ} \mathrm{C}$. DIG-labeled differential DNA fragments were used as candidate probes for screening species-unique repetitive sequence probes on metaphase chromosomes from Hainan 92-77. Chromosomes were counterstained with 4', 6-diamidino-2-phenylindole (DAPI) in a Vectashield anti-fade solution (Vector Laboratories, Burlingame, CA). Detection of DIG with fluorescein isothiocyanate (FITC) and amplification were performed as described by D'Hont et al. [76]. FISH signals were captured using the AxioVision measurement module of an Axio Scope A1 Imager fluorescent microscope (Zeiss, Germany). Based on the FISH results, two primers were designed to accurately identify $E$. arundinaceus authenticity (Additional file 4: Table S1).

\section{Additional files}

Additional file 1: Figure S1. Ligation efficiency of different concentrations of digested gDNA. All lanes include Alul adapter 1 primer 1/204F, Alul adapter 1 primer 1/204R, Alul adapter 2R primer 1/204F, and Alul adapter $2 R$ primer 1/204R with the indicated amount of digested gDNA. Lanes 1-4: 50 ng digested gDNA; Lanes 5-8: 100 ng digested gDNA; Lanes 9-12: 150 ng digested gDNA; Lanes 13-16: 200 ng digested gDNA. (TIF $10089 \mathrm{~kb}$ )

Additional file 2: Figure S2. Electrophoresis of primary PCR products after SSH. M: 100 bp marker; Lanes 1-4: products of subtracted first PCR by $62^{\circ} \mathrm{C}, 64^{\circ} \mathrm{C}, 66^{\circ} \mathrm{C}, 68^{\circ} \mathrm{C} .10 \mu \mathrm{M}$ primers and $0.5 \mathrm{U}$ LA Taq polymerase (a), $10 \mu \mathrm{M}$ primers and $1 \mathrm{U}$ LA Taq polymerase (b), $20 \mu \mathrm{M}$ primers and 0.5 U LA Taq polymerase (c). (TIF $12107 \mathrm{~kb}$ )

Additional file 3: Figure S3. Electrophoresis of secondary PCR products after SSH. M: 100 bp marker; Lanes 1-4: products of subtracted second PCR by $62^{\circ} \mathrm{C}, 64^{\circ} \mathrm{C}, 66^{\circ} \mathrm{C}, 68^{\circ} \mathrm{C} .20 \mu \mathrm{M}$ primers and $0.5 \mathrm{U}$ LA Taq polymerase (a), $20 \mu \mathrm{M}$ primers and $1 \mathrm{U}$ LA Taq polymerase (b), $30 \mu \mathrm{M}$ primers and 0.5 U LA Taq polymerase (c). (TIF $11035 \mathrm{~kb}$ )

Additional file 4: Table S1. Nucleotide sequences used in this study. (XLSX 9 kb)

\section{Abbreviations}

CTAB: cetyltrimethyl ammonium bromide; DAPI: 4', 6-diamidino-2-phenylindole; DIG: digoxigenin; FISH: fluorescence in situ hybridization;

FITC: fluorescein isothiocyanate; SSC: saline-sodium citrate; gDNA: genomic DNA; PCR: polymerase chain reaction; RDB: reverse dot blot; SSH: suppression subtractive hybridization

\section{Acknowledgements}

We thank the Research Institute Ruili Station, the Sugarcane Research Institute of Yunnan Agriculture Science Academy, as well as the Hainan Sugarcane Breeding Station, Guangzhou Sugarcane Industry Research Institute for providing the plant materials used in this study. We greatly appreciate Bioscience Editing Solutions for critically reading this paper and providing helpful suggestions.

\section{Funding}

This work was funded by the National Natural Science Foundation of China (31571730, 31401440, 31771863, http://www.nsfc.gov.cn/) and was supported by an earmarked fund for Modern Agriculture Technology of China (CARS-
170106). This project was also supported by the Natural Science Foundation of Guangdong Province of China (2015A030310286). The funders had no role in study design, data collection and analysis, decision to publish, or manuscript preparation.

\section{Availability of data and materials}

The datasets supporting the conclusions of this manuscript are included within the article and its additional files.

\section{Authors' contributions}

$F Y, Y H$, and $Z D$ designed the research. $F Y, Y H$, and $L L$, performed the experiments. $F Y, Y H, L L, X L, J W, R C, M Z$, and $Z D$ analyzed the results. $F Y, Y H, L L$, $\mathrm{JW}$, and ZD wrote the manuscript. All authors read and approved the final manuscript.

Ethics approval and consent to participate

Not applicable.

\section{Consent for publication}

Not applicable.

\section{Competing interests}

The authors declare that they have no competing interests.

\section{Publisher's Note}

Springer Nature remains neutral with regard to jurisdictional claims in published maps and institutional affiliations.

\section{Author details}

${ }^{1}$ National Engineering Research Center for Sugarcane, Fujian Agriculture and Forestry University, Fuzhou 350002, Fujian, China. ${ }^{2}$ Guangdong Key Laboratory of Sugarcane Improvement and Biorefinery, Guangdong Provincial Bioengineering Institute, Guangzhou, China. ${ }^{3}$ State Key Laboratory for protection and utilization of subtropical agro-bioresources, Guangxi University, Nanning 530004, China. ${ }^{4}$ Key Lab of Sugarcane Biology and Genetic Breeding, Ministry of Agriculture, Fujian Agriculture and Forestry University, Fuzhou 350002, China.

Received: 6 February 2018 Accepted: 5 October 2018

Published online: 06 November 2018

\section{References}

1. Camassola M, Dillon AJ. Cellulases and xylanases production by Penicillium echinulatum grown on sugar cane bagasse in solid-state fermentation. Appl Biochem Biotechnol. 2010;162:1889-900.

2. Girio FM, Fonseca C, Carvalheiro F, Duarte LC, Marques S, Bogel-Lukasik R. Hemicelluloses for fuel ethanol: a review. Bioresour Technol. 2010;101:4775-800.

3. Sarkar N, Ghosh SK, Bannerjee S, Aikat K. Bioethanol production from agricultural wastes: an overview. Renew Energy. 2012;37:19-27.

4. Rabelo SC, Carrere H, Maciel Filho R, Costa AC. Production of bioethanol, methane and heat from sugarcane bagasse in a biorefinery concept. Bioresour Technol. 2011;102:7887-95.

5. Howard RL, Abotsi E, Rensburg EJV, Howard S. Lignocellulose biotechnology: issues of bioconversion and enzyme production. Afr 」 Biotechnol. 2003:2:602-19.

6. Lam E, Jr Shine J, Silva JD, Lawton M, Bonos S, Calvino M, Carrer H, Silva Filho MC, Glynn N, Helsel Z. Improving sugarcane for biofuel: engineering for an even better feedstock. GCB Bioenergy. 2009;1:251-5.

7. Waclawovsky AJ, Sato PM, Lembke CG, Moore PH, Souza GM. Sugarcane for bioenergy production: an assessment of yield and regulation of sucrose content. Plant Biotechnol J. 2010;8:263-76.

8. Paz DSMC, Naiana SJ, Cícero A. Differential detection of transposable elements between Saccharum species. Genet Mol Biol. 2013;36:408-12.

9. Grivet L, Glaszmann JC, D'Hont A. Molecular evidence of sugarcane evolution and domestication. In: Motley TJ, editor. Darwin harvest: new approaches to the origins, evolution and conservation of crops. New York: Columbia University Press; 2006. p. 49-66.

10. Grassl CO. Saccharum robustum and other wild relatives of "Noble" sugar canes. J Arnold Arboretum. 1946;27:234-52.

11. D'Hont A, Paulet F, Glaszmann JC. Oligoclonal interspecific origin of 'north Indian' and 'Chinese' sugarcanes. Chromosom Res. 2002;10:253-62. 
12. Heinz DJ. Sugarcane improvement through breeding. In: Heinz DJ, editor. Plant Breeding Reviews. Amsterdam: Elsevier; 1987. p. 15-118.

13. Amalraj VA, Balasundaram N. On the taxonomy of the members of 'Saccharum Complex'. Genet Resour Crop Ev. 2006;53:35-41.

14. Singh RK, Singh RB, Singh SP, Sharma ML. Identification of sugarcane microsatellites associated to sugar content in sugarcane and transferability to other cereal genomes. Euphytica. 2011;182:335-54.

15. Liu XL, Su HS, Li M, Xin L, Ying XM, Cai Q, Fan YH. Phylogenetic relationships of sugarcane related genera and species based on ITS sequences of nuclear ribosomal DNA. Acta Agron Sin. 2010;36:1853-63.

16. Selvi A, Nair NV, Noyer JL, Singh NK, Balasundaram N, Bansal KC, Koundal KR, Mohapatra T. AFLP analysis of the Phenetic organization and genetic diversity in the sugarcane complex, Saccharum and Erianthus. Genet Resour Crop Ev. 2006;53:831-42.

17. Jing sheng $X U$, Li ping $X U$, Zhang MQ. Fuzhou. Phylogenetic relationships of Saccharum to its relative genus based on RAPD analysis. Acta Agriculturae Universitis Jiangxiensis. 2003;25:925-8.

18. Cordeiro GM, Pan YB, Henry RJ. Sugarcane microsatellites for the assessment of genetic diversity in sugarcane germplasm. Plant Sci. 2003;165:181-9.

19. Pan YB, Burner DM, Legendre BL. An assessment of the phylogenetic relationship among sugarcane and related taxa based on the nucleotide sequence of 5S rRNA intergenic spacers. Genetica. 2000;108:285-95.

20. D'Hont A, Rao PS, Feldmann P, Grivet L, Islam-Faridi N, Taylor P, Glaszmann JC. Identification and characterisation of sugarcane intergeneric hybrids, Saccharum officinarum $\times$ Erianthus arundinaceus, with molecular markers and DNA in situ hybridisation. Theor Appl Genet. 1995;91:320-6.

21. Rott $P$, Mohamed IS, Klett $P$, Soupa D, De S-AA, Feldmann P, Letourmy $P$. Resistance to leaf scald disease is associated with limited colonization of sugarcane and wild relatives by Xanthomonas albilineans. Phytopathology. 1997:87:1202-13

22. Piperidis G, Christopher MJ, Carroll BJ, Berding N, D'Hont A. Molecular contribution to selection of intergeneric hybrids between sugarcane and the wild species Erianthus arundinaceus. Genome. 2000;43:1033-7.

23. Cai Q, Aitken KS, Fan YH, Piperidis G, Jackson P, Mcintyre CL. A preliminary assessment of the genetic relationship between Erianthus rockii and the "Saccharum complex" using microsatellite (SSR) and AFLP markers. Plant Sci. 2005;169:976-84

24. Benavente E, Cifuentes M, Dusautoir JC, David J. The use of cytogenetic tools for studies in the crop-to-wild gene transfer scenario. Cytogenet Genome Res. 2008;120:384-95.

25. Sharma S, Raina SN. Organization and evolution of highly repeated satellite DNA sequences in plant chromosomes. Cytogenet Genome Res. 2005:109: 15-26.

26. Raskina O, Barber JC, Nevo E, Belyayev A. Repetitive DNA and chromosomal rearrangements: speciation-related events in plant genomes. Cytogenet Genome Res. 2008;120:351-7.

27. Orgel LE, Crick FH. Selfish DNA: the ultimate parasite. Nature. 1980;284:604-7.

28. Svitashev S, Bryngelsson T, Li X, Wang RR. Genome-specific repetitive DNA and RAPD markers for genome identification in Elymus and Hordelymus. Genome. 1998:41:120-8.

29. Yan HH, Liu GQ, Cheng ZK, Li XB, Liu GZ, Min SK, Zhu LH. A genome-specific repetitive DNA sequence from Oryza eichingeri: characterization, localization, and introgression to O. sativa. Theor Appl Genet. 2002;104:177-83.

30. Yang S, Li X, Huang F, Huang Y, Liu X, Wu J, Wang Q, Deng Z, Chen R, Zhang M. A new method based on SNP of nrDNA-ITS to identify Saccharum spontaneum and ITS progeny in the genus Saccharum. PLoS One. 2018;13:e0197458.

31. Liu X, Li X, Liu H, Xu C, Lin X, Li C, Deng Z. Phylogenetic analysis of different ploidy Saccharum spontaneum based on rDNA-ITS sequences. PLoS One. 2016;11:e0151524

32. Zhang H, Bian Y, Gou X, Zhu B, Xu C, Qi B, Li N, Rustgi S, Zhou H, Han F, et al. Persistent whole-chromosome aneuploidy is generally associated with nascent allohexaploid wheat. Proc Natl Acad Sci U S A. 2013;110:3447-52.

33. Chen JW, Jackson PA, Lao FY, Liu R. Identification of $B C_{2}$ progeny from Saccharum officinarum $\times$ Erianthus arundinaceus by ISSR markers. Sugar Crops China. 2008;01:1-3

34. Nair NV, Mary S. RAPD analysis reveals the presence of Indian and Indonesian forms of Erianthus arundinaceus (Retz.) Jeswiet. In the AndamanNicobar Islands, India. Curr Sci India. 2006;90:1118-22.

35. Lao F, Fu C, Chen Z, Chen J, Zhang C, Yang Y, Deng H. Molecuar identification of genuine hybrids from the cross of Saccharum and $E$. arundinaceus. Sugarcane Canesugar. 2006;01:6-11.
36. Cai Q, Aitken K, Deng HH, Chen XW, Fu C, Jackson PA, Mclntyre CL. Verification of the introgression of Erianthus arundinaceus germplasm into sugarcane using molecular markers. Plant Breed. 2005;124:322-8.

37. Devos KM, Gale MD. The use of random amplified polymorphic DNA markers in wheat. Theor Appl Genet. 1992;84:567.

38. Souza GM, Berges H, Bocs S, Casu R, D'Hont A, Ferreira JE, Henry R, Ming R, Potier B, Sluys MAV. The sugarcane genome challenge: strategies for sequencing a highly complex genome. Trop Plant Biol. 2011;4:145-56.

39. O'Rourke JF, Pugh CW, Bartlett SM, Ratcliffe PJ. Identification of hypoxically inducible mRNAs in HeLa cells using differential-display PCR. Role of hypoxia-inducible factor-1. Eur J Biochem. 1996;241:403-10.

40. Li TX, Wang J, Bai Y, Sun X, Lu Z. A novel method for screening species-specific gDNA probes for species identification. Nucleic Acids Res. 2004;32:e45.

41. Humann FC, Hartfelder K. Representational difference analysis (RDA) reveals differential expression of conserved as well as novel genes during castespecific development of the honey bee (Apis mellifera L.) ovary. Insect Biochem Mol Biol. 2011:41:602-12.

42. Diatchenko L, Lau YF, Campbell AP, Chenchik A, Moqadam F, Huang B, Lukyanov S, Lukyanov K, Gurskaya N, Sverdlov ED, Siebert PD. Suppression subtractive hybridization: a method for generating differentially regulated or tissue-specific cDNA probes and libraries. Proc Natl Acad Sci U S A. 1996:93: 6025-30.

43. Gurskaya NG, Diatchenko L, Chenchik A, Siebert PD, Khaspekov GL, Lukyanov KA, Vagner LL, Ermolaeva OD, Lukyanov SA, Sverdlov ED. Equalizing CDNA subtraction based on selective suppression of polymerase chain reaction: cloning of Jurkat cell transcripts induced by phytohemaglutinin and phorbol 12-myristate 13-acetate. Anal Biochem. 1996:240:90-7.

44. Luk'ianov SA, Gurskaia NG, Luk'ianov KA, Tarabykin VS, Sverdlov ED. Highlyeffective subtractive hybridization of cDNA. Bioorg Khim. 1994:20:701-4.

45. Rebrikov DV, Desai SM, Siebert PD, Lukyanov SA. Suppression subtractive hybridization. Methods Mol Biol. 2004;258:107-34.

46. Dai ZY, Mao XX, Magnuson JK, Lasure LL. Identification of genes associated with morphology in Aspergillus niger by using suppression subtractive hybridization. Appl Environ Microb. 2004;70:2474-85.

47. Harakava R, Gabriel DW. Genetic differences between two strains of Xylella fastidiosa revealed by suppression subtractive hybridization. Appl Environ Microb. 2003:69:1315-9.

48. Harms C, Kase M, Hildebrandt A. Characterization of minute differences between genomes of strains of Penicillium nalgiovense using subtractive suppression hybridization without cloning. Lett Appl Microbiol. 2002;35: 113-6.

49. Hsieh WJ, Pan MJ. Identification Leptospira santarosai serovar shermani specific sequences by suppression subtractive hybridization. FEMS Microbiol Lett. 2004;235:117-24.

50. Stocki SL, Babiuk LA, Rawlyk NA, Potter AA, Allan BJ. Identification of genomic differences between Escherichia coli strains pathogenic for poultry and E-coli K-12 MG1655 using suppression subtractive hybridization analysis. Microb Pathogenesis. 2002:33:289-98.

51. Galbraith EA, Antonopoulos DA, White BA. Suppressive subtractive hybridization as a tool for identifying genetic diversity in an environmental metagenome: the rumen as a model. Environ Microbiol. 2004;6:928-37.

52. Ge J-Y, Chen S-Q, Gao Y-Y, Gao Y, Zhu X, Huang Z-F, Chen J-M. Development of genome-specific molecular markers for Lophopyrum elongatum based on suppression subtractive hybridization. Acta Agron Sin. 2013;38:1818-26.

53. Piperidis N, Chen JW, Deng HH, Wang LP, Jackson P, Piperidis G. GISH characterization of Erianthus arundinaceus chromosomes in three generations of sugarcane intergeneric hybrids. Genome. 2010;53:331-6.

54. Wu J, Huang Y, Lin Y, Fu C, Liu S, Deng Z, Li Q, Huang Z, Chen R, Zhang M. Unexpected inheritance pattern of Erianthus arundinaceus chromosomes in the intergeneric progeny between Saccharum spp. and Erianthus arundinaceus. PLoS One. 2014;9:e110390.

55. Huang Y, Wu J, Wang P, Lin Y, Fu C, Deng Z, Wang Q, Li Q, Chen R, Zhang $M$. Characterization of chromosome inheritance of the intergeneric $B C_{2}$ and $\mathrm{BC}_{3}$ progeny between Saccharum spp. and Erianthus arundinaceus. PLoS One. 2015;10:e0133722.

56. Akopyants NS, Fradkov A, Diatchenko L, Hill JE, Siebert PD, Lukyanov SA, Sverdlov ED, Berg DE. PCR-based subtractive hybridization and differences in gene content among strains of Helicobacter pylori. P Natl Acad Sci USA. 1998;95:13108. 
57. Lisitsyn NA, Rosenberg MV, Launer GA, Wagner LL, Potapov VK, Kolesnik TB, Sverdlov ED. A method for isolation of sequences missing in one of two related genomes. Mol Gen Mikrobiol Virusol. 1993:26-9.

58. Lisitsyn N, Lisitsyn N, Wigler M. Cloning the differences between two complex genomes. Science. 1993;259:946-51.

59. Straus D, Ausubel FM. Genomic subtraction for cloning DNA corresponding to deletion mutations. Proc Natl Acad Sci U S A. 1990;87:1889-93.

60. Lamar EE, Palmer E. Y-encoded, species-specific DNA in mice: evidence that the $Y$ chromosome exists in two polymorphic forms in inbred strains. Cell. 1984;37:171-7.

61. Agron PG, Walker RL, Kinde H, Sawyer SJ, Hayes DC, Wollard J, Andersen GL. Identification by subtractive hybridization of sequences specific for Salmonella enterica Serovar Enteritidis. Appl Environ Microbiol. 2001;67: 4984-91.

62. Calia KE, Waldor MK, Calderwood SB. Use of representational difference analysis to identify genomic differences between pathogenic strains of Vibrio cholerae. Infect Immun. 1998:66:849-52.

63. Sagerstrom CG, Sun Bl, Sive HL. Subtractive cloning: past, present, and future. Annu Rev Biochem. 1997;66:751-83.

64. Agrawal V, Gupta B, Banerjee UC, Roy N. A method for construction, cloning and expression of intron-less gene from unannotated genomic DNA. Mol Biotechnol. 2008:40:217-23.

65. Wu JR, Pearson WR, Posakony JW, Bonner J. Sequence relationship between long and short repetitive DNA of the rat: a preliminary report. P Natl Acad Sci USA. 1977;74:4382-6.

66. Paesold S, Borchardt D, Schmidt T, Dechyeva D. A sugar beet (Beta vulgaris L.) reference FISH karyotype for chromosome and chromosome-arm identification, integration of genetic linkage groups and analysis of major repeat family distribution. Plant J. 2012;72:600-11.

67. Jiang $L$, You W, Zhang $X$, Xu J, Jiang Y, Wang K, Zhao Z, Chen B, Zhao Y Mahboob S, et al. Construction of the BAC library of small abalone (Haliotis diversicolor) for gene screening and genome characterization. Mar Biotechnol (NY). 2016:18:49-56.

68. Wang K, Zhang YJ, Guan B, Guo WZ, Zhang TZ. Fluorescence in situ hybridization of bacterial artificial chromosome in cotton. Prog Biochem Biophys. 2007;34:1216-22.

69. Lengauer C, Speicher MR, Popp S, Jauch A, Taniwaki M, Nagaraja R, Riethman HC, Donis-Keller H, D'Urso M, Schlessinger D, et al. Chromosomal bar codes produced by multicolor fluorescence in situ hybridization with multiple YAC clones and whole chromosome painting probes. Hum Mol Genet. 1993;2:505-12.

70. Umehara Y, Inagaki A, Tanoue H, Yasukochi Y, Nagamura Y, Saji S, Otsuki Y, Fujimura T, Kurata N, Minobe Y. Construction and characterization of a rice YAC library for physical mapping. Mol Breeding. 1995;1:79-89.

71. Wang K, Song X, Han Z, Guo W, Yu JZ, Sun J, Pan J, Kohel RJ, Zhang T. Complete assignment of the chromosomes of Gossypium hirsutum L. by translocation and fluorescence in situ hybridization mapping. Theor Appl Genet. 2006:113:73-80.

72. Zhang L, Xu C, Yu W. Cloning and characterization of chromosomal markers from a Cot-1 library of peanut (Arachis hypogaea L.). Cytogenet Genome Res. 2012;137:31-41.

73. Zhang W, Zuo S, Li Z, Meng Z, Han J, Song J, Pan YB, Wang K. Isolation and characterization of centromeric repetitive DNA sequences in Saccharum spontaneum. Sci Rep. 2017;7:41659.

74. Kato A, Lamb JC, Birchler JA. Chromosome painting using repetitive DNA sequences as probes for somatic chromosome identification in maize. Proc Natl Acad Sci U S A. 2004;101:13554-9.

75. Stewart CN Jr, Via LE. A rapid CTAB DNA isolation technique useful for RAPD fingerprinting and other PCR applications. BioTechniques. 1993;14: 748-50

76. D'Hont A. Determination of basic chromosome numbers in the genus Saccharum by physical mapping of ribosomal RNA genes. Genome. 1998;41: $221-5$.

Ready to submit your research? Choose BMC and benefit from:

- fast, convenient online submission

- thorough peer review by experienced researchers in your field

- rapid publication on acceptance

- support for research data, including large and complex data types

- gold Open Access which fosters wider collaboration and increased citations

- maximum visibility for your research: over $100 \mathrm{M}$ website views per year

At $\mathrm{BMC}$, research is always in progress.

Learn more biomedcentral.com/submissions 